\title{
Efficacy of plant biomass Leucaena leucocephala and Albizia amara for degradation of textile navy blue dye simulated in Virgin-red soil
}

Sudarmani Gayathri Nehru ( $\sim$ sendanicemail3@gmail.com )

PSG College of Arts and Science,Coimbatore https://orcid.org/0000-0002-4488-9134

Jayanthy Jayanthy Venkatachary

PSG College of Arts and Science

\section{Research Article}

Keywords: Phytoremediation, Leucaena leucocephala and Albizia amara (Plant biomass), Textile dye (Navy Blue dye)

Posted Date: June 2nd, 2021

DOI: https://doi.org/10.21203/rs.3.rs-460134/v1

License: (c) (i) This work is licensed under a Creative Commons Attribution 4.0 International License.

Read Full License 


\section{Abstract}

Phytoremediation a green initiative is one of the major process involved in Phytotechnology. Phytoremediation of textile dye contaminated soil faces a particular challenge which uses plants and their associated rhizospheric microorganisms to remove pollutants from contaminated sites. Unlike other contaminants, dye cannot be degraded. Commonly, decontamination of dye contaminated soils requires the removal of toxic substances. Textile dye discharges pollutes the fertile cultivated land day by day and thus occurs the loss of vegetation, hence an ecofriendly method phytoremediation was carried out to minimise risk of causing the other chemicals for cleaning method to avoid environmental risk as well as health. Recently, phytostabilisation a plant based technologies, the use of plants to extract toxic organic substances from contaminated soils, has emerged as a cost-effective, environment-friendly cleanup alternative. The aim of the present research work is to identify the efficacy of plant biomass Leucaena leucocephala and Albizia amara to remove dye contamination from textile navy blue simulated soils and discusses the effects of agronomic practices on these processes. In this study the two different source of plant is used as biomass so as to minimise the exploitation of using a single source. This were evaluated using the parameters biometric evaluation, biochemical estimation, stress markers, estimation of DNA and DNA profiling by Agarose gel electrophoresis. Challenges progress in the field is hindered by lack of understanding of complex interactions in the rhizosphere and plant based mechanisms which allow dye translocation and chemical accumulation in plants. This research concludes with suggestions for future phytoremediation research.

\section{Introduction}

Phytoremediation a green technology involves growing plants in a contaminated matrix to remove the contaminants by facilitating sequestration or detoxification of any pollutants. Various pollutants are released into the environments among which textile dyes are becoming a cause of concern (Jelic et al.2012). The pollutants which reaches the soil reaches the water and causes pollution in soil affects the fertility of soil (Bafana et al. 2011). Thus to remove the contaminants in soil an ecofriendly method is phytoremediation is chosed so as to reduced the treatment using chemical components in soil.

Phytoremediation using a plant biomass is required to remove the contaminants in soil which increase the growth rate, crop productivity, dense root system, increased levels of degrading enzymes and tolerant to pollution. An advantage in using this green remediation technique is relatively low cost, easy implementation, ability to conjugate with other methods and in situ processing (Pilon-Smits 2005).

Phytoremediation using pod biomass Leucaena leucocephala and leaf biomass Albizia amara was chosen for the study to minimise the exploitation of using a single source and o eliminate risk for crops and helps more vegetation. The ability of selecting species of plants, which are either resistant to dye contaminated soil, would certainly facilitate reclamation of contaminated areas. In addition, soil contamination by means of dyes or chemical substances is known to be phytotoxic to sensitive plants and is of the greatest concerns for human health (Imen Khouni et al. 2010). Exposure to dye can lead to 
carcinogenic effects in humans and in plants leads to death with affects the crop production (Alkorta et al.2004).

In this study, the efficacy of plant biomass Leucaena leucocephala and Albizia amara was evaluated using the test plant Vigna radiata (green gram) with different percentage concentration of textile dye (navy blue dye) simulated virgin red soil. The remediating potential of plant biomass was assessed by identifying the active constituents present using preliminary phytochemical screening, FTIR analysis and GCMS. Range finding test was carried out to study the toxicity level of dye and the maximum of $1 \%$ dye was used for the study.

\section{Materials And Methods \\ Collection of plant material}

The dried pods of Leucaena leucocephala (R1) and leaves of Albizia amara (R2) is taken for the study which is collected from in and around Coimbatore. Both the plants are selected for remediating purposes authenticated in Botanical Survey of India (BSI).BSI verified the remediating material Leucaena leucocephala (R1) and Albizia amara (R2) with the index of BSI/SRC/5/23/12-13/Tech-448 and BSI/SRC/5/23/13-14/Tech-2055.

\section{Preparation of plant adsorbent}

The dry pods of Leucaena leucocephala and leaves of Albizia amara were chosen for the study as phytoremediator. The dry pods of Leucaena leucocephala (R1-remediator 1) were again dried in room temperature and used for the study. The small leaves of Albizia amara was shade dried and used for the study (R2-remediator 2). Thus prepared plant source were used as an adsorbent and carried out for the further analysis. No binding agent was used so as to study the exact nature of Leucaena leucocephala and Albizia amara plant biomass. Range finding test was performed with plant biomass Leucaena leucocephala and Albizia amara with different concentration of dye $0.25 \%, 0.50 \%, 0.75 \%$ and $1 \%$. All the parameters were assessed in dye simulated soil with plant biomass individually and in combined form in ratio 1:1.

\section{Physio-chemical characterization of soil}

Soil is the medium for plant growth. Its physical, chemical and biological properties determine the degree of workability, suitability to specific crop varieties, physical and chemical capacities as well as productivity (Mitchell 2010). Physiochemical analysis for red soil was carried out in selected virgin red soil collected from Sulur belt Coimbatore to understand the soil nature before and after dye simulation. Virgin red soil was selected since it maintains the moisture content and suitable for all sort of the plant growth. This study reveals the changes in $\mathrm{pH}$, lime status and macronutrient such as $\mathrm{N}, \mathrm{P}, \mathrm{K}$ and micronutrients such as zinc, copper and manganese in after simulation of textile navy blue dye.

\section{Seed selection and sterilization}


The seed selected for this experiment is Vigna radiata (green gram) were purchased from the local market. This plant is chosen for this study because of easy availability in all sort of climatic conditions and fast germination. The Vigna radiata was sterilized with $0.1 \%$ mercuric chloride and used for further evaluation (Welbaum and Bradford 1990).

\section{Preliminary phytochemical screening of plant biomass}

Preliminary phytochemical screening of plant biomass Leucaena leucocephala and Albizia amara shows the presence of alkaloids (Waldi 1965), flavonoids (Harborne 1987), tannins (Evans 1997), phenols and Saponins (Mace 1963), carbohydrates (Ramakrishnan and Rajan 1994), proteins (Fischer 1968) in Leucaena leucocephala whereas in Albizia amara leaves the secondary metabolites such as alkaloids, flavanoids, phenols, tannins and protein is present in it.

\section{Spectral analysis with dye and remediating plant material}

FTIR analysis for textile navy blue dye and the plant biomass used in the study was assessed by $\mathrm{KBr}$ pellet method indicates the presence of functional groups primary amines, aromatic amines, alkyl halides, alcohols, carboxylic acids, esters and ethers in Leucaena leucocephala (R1) and Albizia amara (R2) confirmed the presence of alcohols, aldehydes, alkynes, alkanes, carboxylic acids, alkenes, aromatics, aliphatic amines and alkyl halides compounds respectively. Textile navy blue dye shows the functional group nitriles which was not present in plant biomass.

\section{GCMS Analysis}

Plant biomass Leucaena leucocephala (R1) and Albizia amara (R2) powder was used to identify the active constituents present. The spectrum of the unknown component is compared with the spectrum of the known components stored in the NIST library and ascertained the name, molecular weight and structure of the components of the test materials in GC-MS study (Henry and Ducroc 1991). Thus identified active constituents decanoic acids were predominantly present and common for the plant biomass Leucaena leucocephala (R1) and Albizia amara (R2).

\section{Biometric Evaluation}

This study was undertaken to study the biometric parameters of the selected varieties of Vigna radiata the parameters considered for the study are root length, shoot length, plant height and leaf area is measured with the help of thread and measuring scale. The thread was placed attached to the respective position which is to be measured, thus the length, area and height is measured. The values obtained is converted into percentage using the formulas C-T/C*100 (Prasad et al. 2007).

Biochemical estimation and analysis of stress markers in Vigna radiata (green gram) root tissue

The root of green gram (Vigna radiata)were evaluated quantitatively to estimate the total content of carbohydrate, proteins, amylase, DNA and to identify the stress tolerance of biomarkers such as phenols, salicylic acid, hydrogen peroxide, and ascorbic acid. All experiments were repeated three times for precision and values were expressed in mean \pm standard deviation (Senaratna et al. 2000). 


\section{Estimation of DNA by Diphenyl method}

To a series of test tube $0.2-1 \mathrm{ml}$ of standard with concentration $50-250 \mathrm{mg}$ was taken and made upto $3 \mathrm{ml}$ with distilled water and to all the tubes added $5 \mathrm{ml}$ of diphenylamine reagent. After shaking the test tube, kept in boiling water bath upto 10minutes. The aliquots of control, test, R1, R2 and R1 + R2 were also treated as above. The blue colour developed was read spectrophometric at 595nn.A standard graph was plotted. (Ramakrishnan and Rajan 1994).

\section{DNA profiling using Agarose gel electrophoresis}

Pre-warmed $5 \mathrm{ml}$ CTAB(add $10 \mu \mathrm{l}$ mercaptoethanol to each $5 \mathrm{ml} \mathrm{CTAB}$ ) in blue -topped $50 \mathrm{ml}$ centrifuged tube at $60-65^{\circ} \mathrm{C}$. Remove and discard midribs and wrap laminae in aluminium foil and freeze in liquid nitrogen for $1-2$ days at $20^{\circ} \mathrm{C}$ for longer periods. Gently crumble root tissue over cold pestle of liquid nitrogen. Scrape powder into dry tube and add pre-heated buffer and mix gently. Avoid leaving dry and adjust $C T A B$ volume to give a slurry-like consistency, mix occasionally. Incubate the substance for $60 \mathrm{mins}$ at $60^{\circ} \mathrm{C}$.Centrifuge the homogenized solution at $12000 \mathrm{rpm}$ for $5 \mathrm{mins}$.Add equal volume of chloroform: iso amyl alcohol (24:1) proportion and contents to narrow bore centrifuge tubes. Spin $5000 \mathrm{rpm}$ for 10 minutes. Removed supernatant with wide-bore pastette (cut off blue tip)to clean tube, and precipitate DNA with equal volume of ice cold isopropanol can leave it for overnight. Spool out or spin down, $2 \mathrm{mins}$ at $2000 \mathrm{rpm}$. Wash the DNA pellet with $70 \%$ ethanol. Dry briefly and re-suspended in $1 \mathrm{ml}$ of $1 \mathrm{X}$ TE buffer. Add $1 \mu \mathrm{l}$ of $10 \mathrm{mg} / \mathrm{ml}$ RNAse to each $1 \mathrm{mlTE} / \mathrm{DNA}$ mixture and incubate for $60 \mathrm{mins}$ at $37^{\circ} \mathrm{C}$ and spin at $5000 \mathrm{rpm}$ for $10 \mathrm{mins}$. The white thread like DNA is spooled out and air dried and re-suspended in 0.5 to $1 \mathrm{ml} \mathrm{TE}$ or Nuclease free water and freeze until required. Check the purity of isolated DNA using agarose gel electrophoresis (Reddy Prasad et al. 2012).

\section{Statistical analysis}

All experiments were performed by two way ANOVA, post doc, LSD (SPSS version 10.0), $p<0.05$ were considered as statistically significant in duplicate and the standard error of the mean values was calculated. The means were tested according to Students t-test for significant differences among the samples. A statistical significance was accepted at $\mathrm{P}<0.05$.

\section{Result And Discussion}

A pot experiment was carried out with three different percentage of dye from minimum concentration of $0.25 \%, 0.5 \%, 0.75 \%$ and maximum concentration upto $1 \%$ to categorize the growth level of green gram using a plant biomass Leucaena leucocephala (R1-remediator1), Albizia amara (R2-remediator 2) and combination of both Leucaena leucocephala and Albizia amara (R1 + R2).

\section{Biometric Evaluation}

Biometric evaluation of root length, shoot length, plant height and leaf area were evaluated in Vigna radiata (green gram) plant before and after remediation. 
Figure 1 shows the developmental status of Vigna radiata, root length, shoot length, plant height and leaf area was reduced in dye simulated soil when compared to remediated and control soil. At all the four different concentrations of dye, the plant grown in remediated soil has better growth.

When comparison done within the plant biomass, the combined form of plant biomass (1:1) (R1 + R2) shows the better effect in the shoot length of plant Vigna radiata (green gram). Thus dye contaminated soil reduces the shoot growth in green gram due to their increase in toxicity and through the implement of phytoremediator in dye simulated soil shows good growth potential of plant Vigna radiata (green gram).

\section{Biochemical estimation of Vigna radiata (green gram)}

Since the maximum concentration of $1 \%$ is toxic upto the analysis of biometric evaluation, all the biochemical estimation carried out with $1 \%$ dye and followed. Plants are exposed to several environmental constrains generally attributed to abiotic and biotic stresses induced by pathogens. Abiotic stress factors belong to the main environmental factors affecting crop growth and productivity. Abiotic stress environment can induce a wide number of responses in plants ranging from readjustment of transport and metabolic processes leading to growth inhibition (Tardif et al. 2009).

Biochemical estimation of protein, amino acids, carbohydrate, DNA and amylase were carried out in Vigna radiata (green gram) root tissue after the 17th day of germination. A comparison between control, dye simulated and remediated roots were made. The root systems perform many essential adaptive functions including water and nutrient uptake, anchorage to the soil and the establishment of biotic interactions at the rhizosphere and so all the biochemical studies carried out in it. The biochemical changes observed for protein, amino acids, and total carbohydrates. Amylase is the first enzyme that gets activated on germination was also measured. The stress markers and antioxidant levels were studied for the abiotic stress induced by navy blue dye on Vigna radiata (green gram).

Table: 1 results the biochemical estimation of protein, amino acids, total carbohydrates and amylase activity in all five groups of plant roots of Vigna radiata (green gram). The plant grown in dye simulated soil shows significant decrease of protein, free amino acids, DNA, total carbohydrates and amylase activity at $\mathrm{p}<0.05$ level. The plant biomass Leucaena leucocephala (R1), Albizia amara (R2) and combined plant biomass (R1 + R2) used for phytoremediation enhances the root growth and improved the biochemical activity in it shows significant increased in protein, free amino acids, DNA, total carbohydrates and amylase. On comparing the plant biomass Leucaena leucocephala and combined plant biomass (R1 + R2), Albizia amara shows statistical significance increase in protein, free amino acids, DNA, total carbohydrate and amylase of plant roots Vigna radiata at $\mathrm{p}<0.05$ level with standard control.

Table 2 explains the presence of stress markers such as phenol, salicylic acid, hydrogen peroxide and ascorbic acid level in plant roots of Vigna radiata (green gram) grown on before and after phytoremediation. The stress markers phenol salicylic acid and ascorbic acid level in plant roots of Vigna radiata (green gram) is significantly decreased in dye simulated soil whereas hydrogen peroxide level 
increases when compared to control and phytoremediator. The phytoremediator of plant biomass Leucaena leucocephala (R1), Albizia amara(R2) and combined form of plant biomass (R1 + R2) was used in this stressed soil. The phytoremediator used in this study enhances the plant growth and shows a significant increase in phenol content, salicylic acid, ascorbic acid and hydrogen peroxide shows significant decrease in the root of Vigna radiata (green gram).

Table 1

Biochemical analysis in green gram root

\begin{tabular}{|c|c|c|c|c|c|}
\hline Groups & $\begin{array}{l}\text { Total protein ( } \mathrm{mg} / \mathrm{g} \\
\text { of tissue) }\end{array}$ & $\begin{array}{l}\text { Amino acids (mg/g } \\
\text { of tissue) }\end{array}$ & $\begin{array}{l}\text { DNA } \\
\text { (mg/g of } \\
\text { tissue) }\end{array}$ & $\begin{array}{l}\text { Total } \\
\text { carbohydrates } \\
\text { (mg/g of } \\
\text { tissue) }\end{array}$ & $\begin{array}{l}\text { Amylase } \\
\text { (mg/g of } \\
\text { tissue) }\end{array}$ \\
\hline $\begin{array}{l}\text { Control } \\
(\mathrm{G} 1)\end{array}$ & $28.3 \pm 1.18$ & $0.16 \pm 0.01$ & $1.91 \pm 0.11$ & $35.1 \pm 1.41$ & $\begin{array}{l}59.7 \pm \\
1.19\end{array}$ \\
\hline $\begin{array}{l}\text { Test } \\
\text { (G2) }\end{array}$ & $16.7 \pm 0.97 * a$ & $0.34 \pm 0.01 * a$ & $\begin{array}{l}1.03 \pm \\
0.07 * a\end{array}$ & $10.8 \pm 1.09 * a$ & $\begin{array}{l}28.9 \pm \\
0.80 \star a\end{array}$ \\
\hline $\mathrm{AA}(\mathrm{G} 3)$ & $\begin{array}{l}38.8 \pm 1.57 \\
a * /(n s)\end{array}$ & $0.18 \pm 0.02 a^{*} /(\mathrm{ns})$ & $\begin{array}{l}2.78 \pm 0.09 \\
a^{\star} /(n s)\end{array}$ & $\begin{array}{l}30.1 \pm 1.33 \\
*_{a} /(n s)\end{array}$ & $\begin{array}{l}70.8 \pm \\
1.29 \\
\star a /(n s)\end{array}$ \\
\hline LL(G4) & $\begin{array}{l}36.6 \pm 1.39 \\
a * /(n s)\end{array}$ & $0.14 \pm 0.02 \mathrm{a} /(\mathrm{ns})$ & $\begin{array}{l}2.55 \pm 0.08 \\
*_{a} /(n s)\end{array}$ & $\begin{array}{l}29.5 \pm 1.12 \\
* a /(n s)\end{array}$ & $\begin{array}{l}61.6 \pm \\
1.13 \\
a * / * a b\end{array}$ \\
\hline $\begin{array}{l}A A+L L \\
\text { (G5) }\end{array}$ & $\begin{array}{l}39.5 \pm 1.70 \\
* a /(n s)\end{array}$ & $\begin{array}{l}0.21 \pm 0.02 \\
\star a / * a b\end{array}$ & $\begin{array}{l}2.99 \pm 0.12 \\
* a /(n s)\end{array}$ & $\begin{array}{l}34.5 \pm 1.48 \\
a * /(n s)\end{array}$ & $\begin{array}{l}69.6 \pm \\
1.20 \\
* a /(n s)\end{array}$ \\
\hline \multicolumn{6}{|c|}{ 1unit of amylase activity $=\mu$ moles of maltose released } \\
\hline \multicolumn{6}{|c|}{ Values are mean $\pm \mathrm{SD}$ of $\mathrm{n}=6$; Group comparison: $\mathrm{G} 1$ vs $\mathrm{G} 2 ; \mathrm{G} 2$ vs $\mathrm{G} 3, \mathrm{G} 4, \mathrm{G} 3$, G4 vs $\mathrm{G} 5$} \\
\hline Statistic & ignificance- $p<0.05^{\prime}$ & ab significant; $b$ no & ference & & \\
\hline
\end{tabular}


Table 2

Stress marker level in Vigna radiata (green gram) root before and after remediation

\begin{tabular}{|c|c|c|c|c|}
\hline Groups & $\begin{array}{l}\text { Phenol } \\
\text { content } \\
\text { ( } \mu \text { moles/g } \\
\text { tíssue) }\end{array}$ & $\begin{array}{l}\text { Salicyclic acid } \\
\text { content( } \mathrm{\mu moles} / \mathrm{g} \\
\text { tissue) }\end{array}$ & $\begin{array}{l}\text { Hydrogen } \\
\text { peroxide level } \\
\text { ( } \mu \text { moles } / g \\
\text { tíssue) }\end{array}$ & $\begin{array}{l}\text { Ascorbic acid level ( } \mathrm{mg} / \mathrm{g} \\
\text { of tissue) }\end{array}$ \\
\hline Control & $98 \pm 1.93$ & $21.7 \pm 0.46$ & $53.9 \pm 0.60$ & $49.4 \pm 0.79$ \\
\hline Test & $49.9 \pm 0.70 a$ & $9.8 \pm 0.49 a$ & $78.9 \pm 0.80 a$ & $11.6 \pm 0.40 \mathrm{a}$ \\
\hline A.amara & $\begin{array}{l}1.22 \pm \\
1.44 a b\end{array}$ & $20.6 \pm 0.48 a b$ & $44.5 \pm 0.758 \mathrm{ab}$ & $43 \pm 0.72 \mathrm{ab}$ \\
\hline L.leucocephala & $\begin{array}{l}1.20 \pm \\
1.49 \mathrm{ab}\end{array}$ & $11.5 \pm 0.47 a b$ & $40 \pm 0.74 a b$ & $41 \pm 0.78 \mathrm{ab}$ \\
\hline $\begin{array}{l}\text { A.amarat } \\
\text { L.leucocehala }\end{array}$ & $\begin{array}{l}1.09 \pm \\
1.81 \mathrm{ab}\end{array}$ & $10.6 \pm 0.43 a$ & $41.3 \pm 0.76 a b$ & $42.4 \pm 0.51 \mathrm{ab}$ \\
\hline \multicolumn{5}{|c|}{ Values are mean $\pm S D$ of $n=6$; } \\
\hline \multicolumn{5}{|c|}{ Group comparison: $\mathrm{G} 1$ vs $\mathrm{G} 2 ; \mathrm{G} 2$ vs $\mathrm{G} 3, \mathrm{G} 4, \mathrm{G} 3, \mathrm{G} 4$ vs $\mathrm{G} 5$} \\
\hline Statistical signifi & nce- $p<0.05$ & ab significant; $b^{*}$ & difference & \\
\hline
\end{tabular}

On comparing the plant biomass Leucaena leucocephala (R1) and combined form of plant biomass (R1 + R2) the plant biomass Albizia amara (R2) shows better improvement in stress markers level. Phenols are one of the important phytochemicals which generally thought to prevent oxidative damage by scavenging active oxygen species and by grating the radical chain reaction during lipid peroxidation (Sakihama and Yamasaki 2002).

\section{Estimation of DNA}

Figure 2 shows the presence of DNA content in root extract of Vigna radiata before and after remediation with $A A, L L$ and $A A+L L$. It was observed that the DNA content was decreased in test roots of Vigna radiata (green gram) when compared with control and remediated roots. The DNA content in remediated roots was high when compared with dye simulated and control roots. The high amount of DNA was present in the remediated roots of $A A, L L$ and $A A+L L$. When comparing within the remediator combined form of AA+LL ( $2.99 \mathrm{mg} / \mathrm{g}$ of root tissue) shows DNA content upto $2.99 \mathrm{mg} / \mathrm{g}$ of tissue.

\section{b) DNA profiling}

For quality and yield assessments, electrophoresis was done with all DNA samples in $0.8 \%$ agarose gel, stained with ethidium bromide and bands were observed in gel documentation system (Fisher 1968). DNA profiling before and after remediation shows a thick single band of high molecular weight confirmed the good quality of the extracted DNA. No DNA fragmentation due to shearing of DNA during extraction procedure was seen in any of samples and results were reproducible (Fig. 3). The DNA profile of the root 
tissue Vigna radiata (green gram) of control, test and remediated plants shows a band at $1500 \mathrm{Kbs}$. Thus, from this observation it explains that the DNA content was high in the entire root sample. DNA isolated produced good quality and high quantity of intact DNA. The intact double standard DNA forming

\section{Conclusion}

The study involved the assessment of biometric levels of plant growth followed by biochemical and stress parameters as indices of growth of Vigna radiata (green gram). Biometric studies showed that the germination rate of this plant was enhanced with means of phytoremediator Leucaena leucocephala (R1), Albizia amara (R2) and combined form of plant biomass (R1 + R2) treated soil in comparison with seeds germinated in dye contaminated soil. This results was supportive with root and shoot length evaluation. Delayed germination and slow growth rate was predominant in dye contaminated soil in contrast to remediated soil.

Biochemical estimation and stress markers level in root tissue of Vigna radiata (green gram) before and after remediation shows significant increased in protein, total carbohydrate, and amylase and decreased in amino acids when compared to dye simulated soil. The phytoremediator of plant biomass Leucaena leucocephala (R1), Albizia amara (R2) and combined form of plant biomass (R1 + R2) used in this experiment shows better growth of plant species Vigna radiata (green gram). When comparison done within the remediator Albizia amara shows better results.

DNA profiling shows the common and intact band at $1500 \mathrm{Kbs}$ in all the root tissue of Vigna radiata (green gram) indicates that the DNA was good and high quality DNA. When the content of DNA was observed between the control, test and remediated roots, the DNA content was high in combined form of plant biomass when compared to the other.

Plantbiomass used in this study have an efficacy to clean up the dye contaminants in soil and they adsorb easily. Phytoremediation a green technology is a cost and effective technique which will not affect the people who live and work around the area while it is being cleaned up and is perceived as a more natural solution than large amounts of equipment and noisy machinery. Thus it proves that the plant biomass Leucaena leucocephala (R1), Albizia amara (R2) has good efficiency on textile dye simulated red soil.

\section{Declarations}

\section{Ethics approval and consent to participate}

Not applicable for my studies because study undergone in phytoremediation only plant was used and authenticated in Botanical Survey of India, Agricultural University-Coimbatore. Reference number was mentioned above in the manuscript in Materials \& Methods.

\section{Consent for publication}


Consent for publication is not applicable

\section{Availability of data and materials}

Availability of data and materials is not applicable

\section{Competing interests}

The authors declare that they have no competing interests.

\section{Funding}

Funding is not applicable

\section{Authors' contributions}

\section{Author contributions of first author and corresponding author were Investigation [Dr. Sudarmani Gayathri $\mathrm{N}]$, Writing original draft-Preparation, Supervision[Dr.Jayanthy V]}

\section{References}

1. Alkorta IJ, Hernández-Allica J, Becerril I, Amezaga IA, Garbisu C (2004) Recent findings on the phytoremediation of soils contaminated with environmentally toxic heavy metals and metalloids such as zinc, cadmium, lead, and arsenic. Rev Environ Sci Biotechnol 3(1):71-90

2. Bafana A, Devi SS, Chakrabarti T (2011) Azo dyes: past, present and the future. Environmental Reviews 19:350-370

3. Evans WC (1997) An index of medicinal plants. A Text book of Pharmacognosy. 14 ed. 7(5) 12-14

4. Fisher DD (1968) Protein staining of ribboned upon section for light microscopy. Histochemistry 16:81-96

5. Harborne JB (1987) Methods in Plant Biochemistry: Academic Press; London 1987

6. Henry YC, Ducroc Q (1991) Nitric oxide a biological effector. Eur biophysics J 20:1-15

7. Imen K, Benoit M, Raja BA (2010) Decolourization of the reconstituted dye bath effluent by commercial laccase treatment: Optimization through response surface methodology. Chem Eng $\mathrm{J}$ 156:121-133

8. Jelic A, Gros M, Petrovic M, Ginebreda A (2012) Occurrence and Elimination of Pharmaceuticals during Conventional Wastewater Treatment. Hdb Env Chem 19:1-24

9. King RW, Richards RA (1984) Water uptake in relation to preharvest sprouting damage in wheat. Grain characteristics. Aust J Agr Res 35:337-345

10. Mace ME (1963) Histochemical localization of phenols in healthy and diseased tomato roots. Phytochem 16:915-925 
11. Mitchell CC (2010) Research-based soil testing interpretation and fertilizer recommendations for cotton on Coastal Plain soils. Sou Coop Ser Bul No. 410.Ala Agric Exp Stn. Auburn University, AL. Electrochemical methods. Water Res 28: 277-282

12. Mohan BS, Hositti BB (1999) Aquatic plants for toxicity assessment. Environ Res 81:259-274

13. Pilon-Smits E (2005) Phytoremediation Annual review of plant biology 56:15-39

14. Prasad J, Tarun K, Sandhar NS, Majumdar G, Patil PG, Shukla SK, Jaiswal BN, Patil AB (2007) Performance evaluation of spindle type cotton picker. J Agric Engg 44(1):38-42

15. Ramakrishnan S, Rajan R (1994) Text book of Medical Biochemistry, 2nd edn. Orient Longman, New Delhi, p 582

16. Reddy Prasad DM, Amirah Izam MD, Maksudur RK (2012) Jatropha curcas: Plant of medical benefits. Journal of Medicinal Plants Research 6(14):2691-2699

17. Sakhima Y, Yamasaki H (2002) Lipid peroxidation induces by phenolics in conjunction with aluminium ions. Biol Plantarum 45:249

18. Senaratna T, Touchell D, Bunn E, Dixon K (2000) Acetyl salicylic acid (Aspirin) and salicylic acid induce multiple stress tolerance in bean and tomato plant. Plant Growth Regul 30:157-161

19. Waldi D (1951) In Thin-layer chromatography. A laboratory handbook. (Edited by Egon Stahl. Academic Press, Inc., New York. 491

20. Wang C, Yediler A, Linert D, Wang Z, Kettrup A (2002) Toxicity evaluation of reactive dye stuff, auxiliaries and selected effluents in textile finishing industry to luminescent bacteria Vibrio fisheri. Chemosphere 46:339-344

21. Welbaum GE, Bradford KJ (1990) Water relations of seed development and germination in muskmelon (Cucumis melo L.V) Water relations of imbibitions and germination. Plant Physio 192:1046-1052

\section{Figures}





Figure 1

Biometric assessment of Vigna radiata (green gram) 


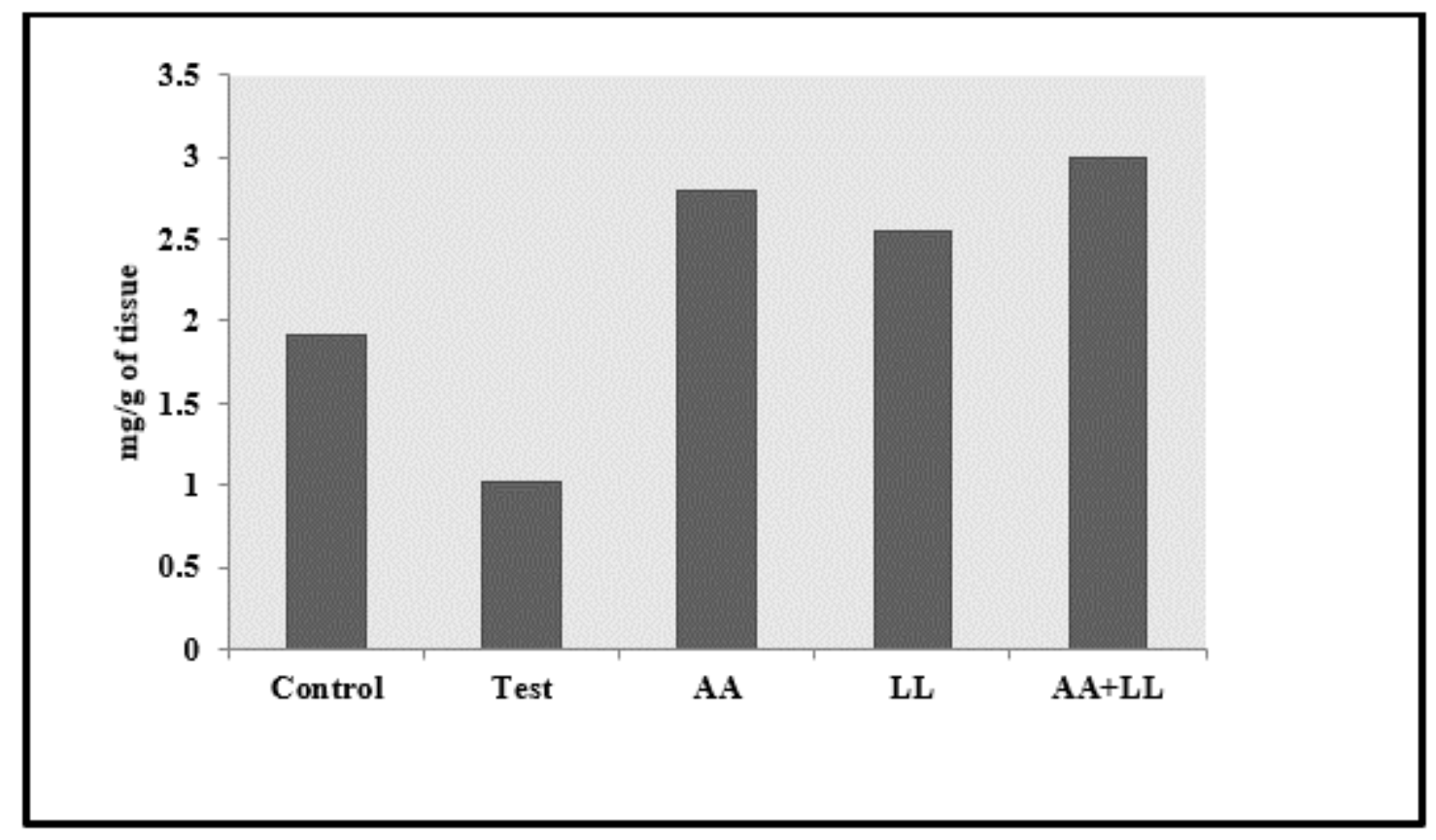

Figure 2

Estimation of DNA content in root tissue of Vigna radiata (green gram)



Figure 3

Agarose Gel Electrophoresis on root tissue Vigna radiata (green gram) 